\title{
Egypt: From Upper Egyptian Rural Petty Polities to Territorial Unitary State
}

\section{Francis David Lankester}

Independent scholar

\begin{abstract}
This paper covers the rise of the Egyptian state from the beginnings of sedentism in the Upper Egyptian Nile Valley to the Early Dynastic period. It examines the contributions which may have been made to this process by Egypt's geography, urbanism, ideology, population pressure and conflict. It appears that Predynastic Egypt at all times had a rural character with elite, but not significantly urban, centres. A likely strong factor assisting elite control was transparency of agricultural production due to the ease of surveillance in a narrow River Nile floodplain. Moreover, Upper Egypt constituted a relatively small and easily controllable area. The early Egyptian state appeared here and then dominated the Nile Delta. Egypt is best seen as a series of rural polities coalescing into an Upper Egyptian rural petty state in which the acquisition of prestige items and a legitimising ideology played important parts, which then expanded into a Lower Egypt which was probably not organised at state level.
\end{abstract}

Keywords: Naqada, sedentism, rural, transparency, violence, population.

\section{EFFECT OF EARLY SEDENTISM}

Egyptian archaeology presents a problem concerning the evidence for the onset of sedentism in the Nile valley. For the Badarian Period (ca 4400-3800 BC; Dee et al. 2013) the view has been presented that Sudan and Egypt along the Nile Valley constituted a primary pastoral community (Wengrow et al. 2014), with limited evidence for agriculture and that sedentism comprehensively begins in the Naqada I period (3800-3600 BC approx.). The effect of climate on settlement and economy is outlined by Kuper and Kröplin (2006). After 7000 BC,

Social Evolution \& History, Vol. 20 No. 1, March 2021 37-64

(C) 2021 'Uchitel' Publishing House

DOI: $10.30884 / \mathrm{seh} / 2021.01 .02$ 
cattle pastoralism became established together with widespread seasonal human settlement. Then from $5300 \mathrm{BC}$ the monsoon rains retreated southward to the pattern they occupy today, and apart from in the oases settlement in Egypt was restricted to the Nile Valley (Brooks 2004). Due to increasing aridification a pastoral economy had become unviable and people were forced into the Nile Valley (Wengrow et al. 2014). By 3500 BC, desert conditions had become established and even favourable areas such as the western highlands of Gebel Uweinat and the Gilf el Kebir were no longer permanently occupied. Unfortunately, it is difficult to determine conclusively how nomadic or sedentary the Badarians were or how involved they were in agriculture. The core of the 'Badarian Civilisation' is in Middle Egypt with sites also in Upper Egypt at Maghar Dendera, Hierakonpolis, El Kab and in the Eastern Desert (Newell 2012). These habitation sites comprise seasonal herding camps. They could be unrepresentative of the settlement pattern as any floodplain villages are now under the modern cultivation and inaccessible to investigation. Evidence for widespread use of cereals is also inconclusive (Newell 2012). It is reasonable to conclude that the Badarians practised a mixed economy of hunting, fishing, gathering and some cultivation. Therefore, we may be able to push back the beginnings of sedentism into the Badarian epoch. Even so, the period in which state formation took place would be approximately 600-700 years, a tenth of the time it took in the Near East from the beginning of agriculture.

Former pastoral communities may have settled in kinship groups, with lineage cores having access to the best land, a situation common in African history where pastoralists were often organised hierarchically and where land was reallocated annually according to primacy of order of settlement (Park 1992). Those on the periphery would have had to work lower quality land and were short of land after a low flood, getting into debt and having to repay through labour service. Moreover, kin relations would have been spread over a wider area than one settlement creating ties, alliances and mutual responsibilities and therefore the situation would not have been one of pristinely autonomous villages. If they originally had a conical clan structure, then the junior lineages would have gradually branched away leaving the senior group established as the founding ancestors. Rather than developing over a long time period lineage hierarchy and a settlement hierarchy could have operated together from sedentism's beginning. We have some limited evidence from cemeteries even from the mainly pastoralist Badarian pre-Naqada period that there was inherited rather 
than ascribed status, particularly from the enhanced burial treatment of some children (Anderson 1992).

We can conclude that the low desert sites, often identified as the first agricultural settlements, in fact constituted elite centres from an early stage. This accounts for the seemingly precocious elements of mortuary display at sites such as at Hierakonpolis where leading lineages planted themselves in the landscape in Naqada I. Elaborate graves (Fig. 1) and pillared halls (Fig. 2) at HK6 date from this period. Some of the most elaborate scenes on C-Ware from Abydos Cemetery U (Fig. 3) dating to early Naqada I (Hartmann 2011) show riverine and desert hunting, representing the claim of the elite leadership to control the wild dangerous forces within and without the Nile Valley. This theme is paralleled in the rock-art of the Eastern Desert.

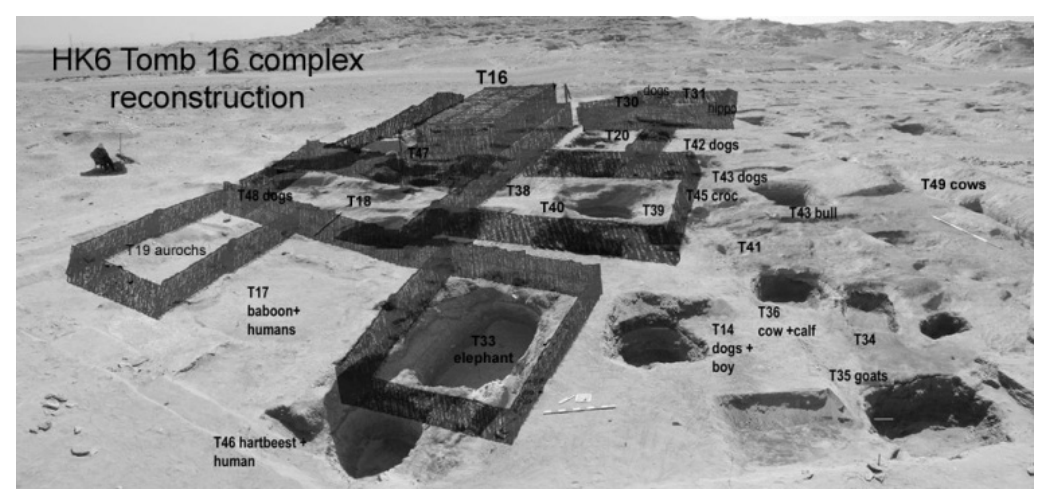

Fig. 1. Naqada I site HK6 tombs

Source: Hierakonpolis Online

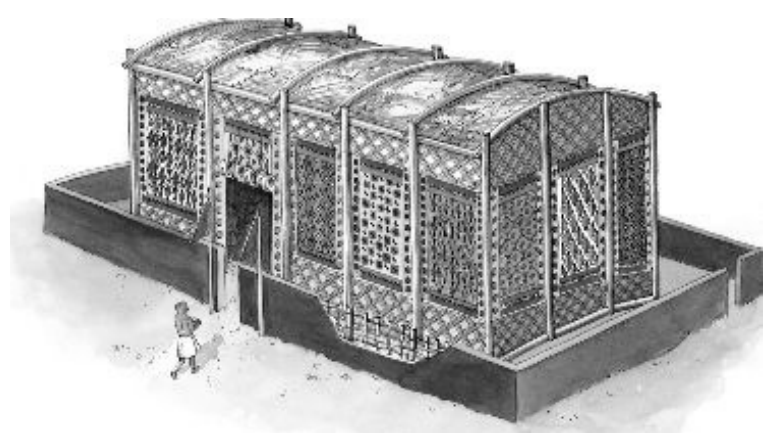

Fig. 2. Hierakonpolis Naqada I pillared hall reconstruction Source: Hierakonpolis Online 


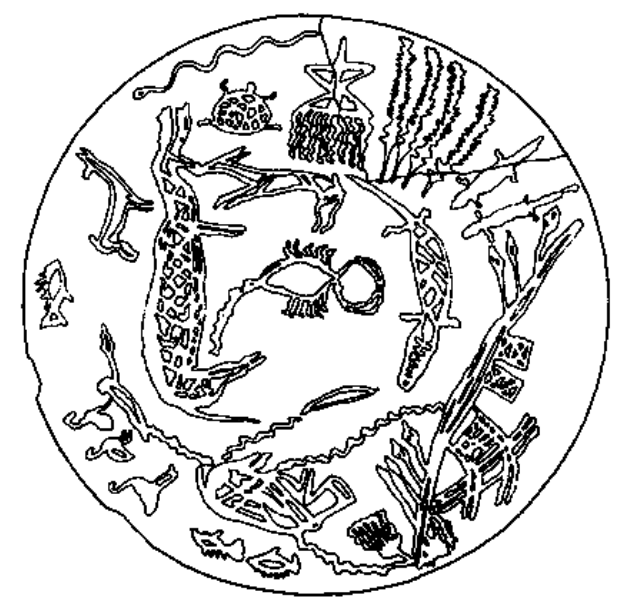

Fig. 3. Early Naqada I C-Ware scene showing hunting of both riverine and desert animals, Abydos U-264 Source: Hendrickx 2011

\section{CREATING AND REINFORCING RANK}

Nile Valley dwellers became permanently settled communities and hunting declined in importance from 10 per cent of meat consumption during the Badarian era to 1 per cent in Naqada I where it became purely an elite activity (Hendrickx 2011). Pottery scenes are mirrored by the importance of hunting in the desert rock-art where men with dogs and missile weapons, dogs alone, and even boats run down prey (Figure 4). Animals are often portrayed very unrealistically (Figures 5 and 6) because to be effective in a liminal area they had to be extraordinary. The rock-art's environment was very different from the comforting, familiar riverside with the repeated rhythm of the seasons and annual inundation. Hunting expeditions moved from the realm of the ordered activities of agricultural life into another realm, remote and outside the regular temporality of life by the Nile. To the sedentary valley inhabitants, the desert would have represented the liminal 'out there;' an area of mystery and wonder, symbolically remote from everyday life (Garwood 2011). The hunters departed from the normal social world and in the wilderness experienced timelessness, otherness, symbolic communication through the rock-art, and sacralisation of their identity as 'Hunting in sedentary societies acquires value above and beyond its subsistence role as transgression of boundaries' (Hamilakis 2003: 240). Only probably a limited number of elite figures would have 
dared and been permitted to undertake the journey, with both their departure and return being publicly witnessed and celebrated. Their return would have been calculated to impress and instil wonder, with the hunters displaying new feathers and prestige products from the desert, quarry and distant sea having accomplished a seemingly superhuman task.

The hunters returned as special people; as heroes with power having overcome the wild, and now with enhanced authority to dominate the normal social, ordered world. Their return was likely celebrated with feasting, seen in faunal remains from Mahasna and Hierakonpolis which included wild desert and dangerous riverine animals: large perch and catfish appropriate to large-scale figures with appropriately god-like appetites (Anderson 2006; Friedman 2011). Ostrich eggs, carnelian, greywacke for palettes, gold and live game together represented an 'ideological currency' in which possession of valuables indicated special skill and therefore worthiness of respect. Moreover, many petroglyph scenes depict control and capture, not killing, so comprising part of the process by which the authority of the elite was produced, reproduced and legitimated (Lankester 2013). These expeditions into another realm would also have reinforced the elites' confidence and solidarity. The precipitate decline in hunting from the Badarian period and the mass of the population accustomed to life in their village positioned the leaders even further apart from the led, for now they claimed power over the land of the wild, the dangerous and the dead. Indeed, into the Early Dynastic period we see the ruler personified as various wild animals such as a bull or lion, finally becoming the living Horus falcon.

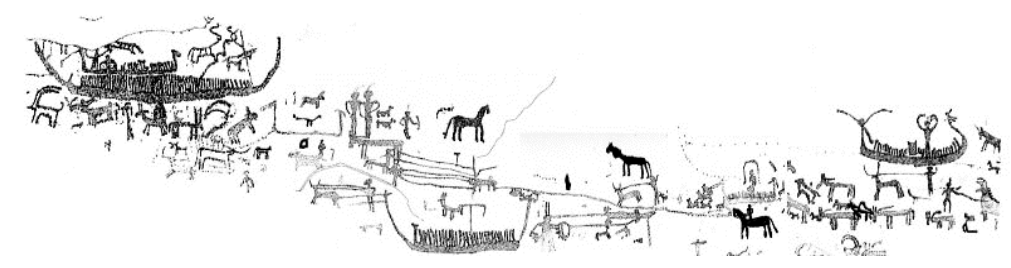

Fig. 4. Boats actively participating in rock-art hunting scene, Wadi Baramiya

Source: Fuchs 1991 


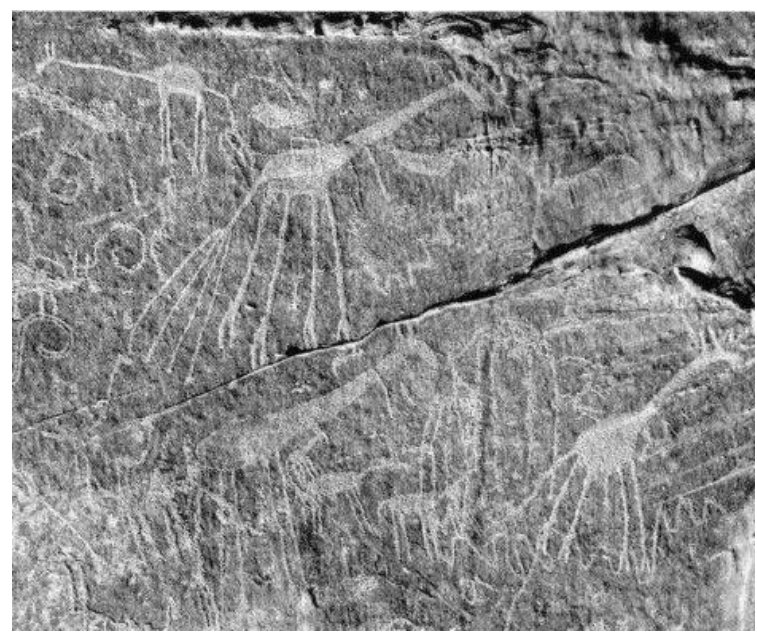

Fig. 5. Unrealistic giraffes, Wadi Umm Salam, Eastern Desert Source: author's photo

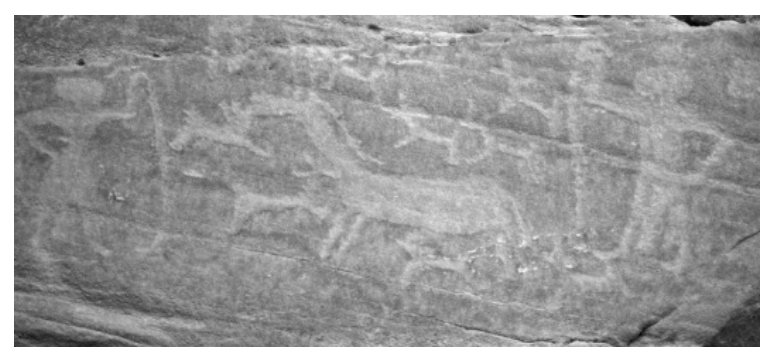

Fig. 6. Unrealistic ass with impossibly detached flowing mane, Wadi Umm Salam, Eastern Desert Source: author's photo

\section{EARLY EGYPT: URBAN OR RURAL?}

There is extremely limited data regarding settlement on the Nile floodplain as any evidence is now beneath the modern cultivation. Cemeteries in the low desert have been surveyed for the whole of the Predynastic period in Upper Egypt. The words $z m t$ and $h r(t)$-netjer meaning 'cemetery' or 'necropolis' linguistically have 'desert' as an integral component (Patch 1991: 90). But this assumes that settlements on the low desert were typically normal farming villages and towns, and that Egyptians of all classes achieved a formal burial. Surveys of the Hierakonpolis (Harlan 1985) and Abydos (Patch 1991) area cemeteries indicate that actually these sites had very small populations. 
For the Abydos region as a whole they are Naqada Ic-IIb: 530, Naqada IIc-d2: 216, Naqada IIIa1-b: 109+, Early Dynastic: 49+, Dynasties IIIIV: 112, Dynasties V-VI: 150 (Patch 1991: 338-339). Hierakonpolis is often claimed as an early urban centre with a population based on site size ranging from 1500 (Harlan 1985) to 2,500-10,000 (Hoffman 1982). However, since no more than 20 actual dwellings have been located, a number may have been herders' camps and others not occupied contemporaneously, these figures cannot be maintained. Moreover, only approximately 1550 graves have been located here for the whole of the Predynastic (Hierakonpolis Online). A figure of 86 has even been suggested as the generational population here (Hoffman 1987b: 189). An estimate of 800 for Naqada's population from 3000 graves also cannot be sustained (Patch 1991).

Egyptian terms for settlements may be helpful. Niwt's earliest meaning is simply 'settlement,' and only later describes much larger sites including a city. Often portrayed as representing a circular, perhaps walled, settlement with two main roads running through it this is speculative as there is no primary textual evidence. An alternative related to canals and water basins has been suggested (Troy 2003: 3). It may represent one surrounded by a protective dyke against being swamped by the inundation. Dmi, from 'to land'/ 'arrive,' but also translated as 'village' or 'town,' was perhaps originally a mooring facility along the riverbank. wHyt can also mean village or town, having its root in 'clan' or 'family' (Troy 2003: 4) suggesting many settlements were based on an extended family. Thus, we have later linguistic support for the contention that settlements were on the riverbank and the floodplain, and were family units rather than urban ones with differentiated neighbourhoods.

It has been suggested that from Naqada IIc/d onwards farming villages originally competed for prestige arising from farming success which proved the headman's ritual power (Kemp 1989; Maisels 1999). Agricultural towns then formed from extended farming villages, fought to control their hinterland and fortified themselves (Fig. 7). These fortified towns then struggled for predominance and became regional capitals such as Hierakonpolis, Naqada and This, one of which emerged to unite Upper Egypt and finally control Middle and Lower Egypt to form the world's first territorial state. However, during Naqada I/IIa a dozen Upper Egyptian sites have the fine C-Ware in significant grave good assemblages. With the exception of Mahasna near Abydos and Ma'mariya near Hierakonpolis, these are roughly evenly spaced, suggesting that they may be chiefs' or sub-chiefs' administrative sites located for ease of control and sending messages. 
From early Naqada II cemetery deposits of exotic goods from Nubia, Lower Egypt and the Near East indicate increased importance of trade, and these could have been used as a political currency by local rulers to secure their followers' loyalty (Midant-Reynes 2000).

In the subsequent Naqada IIc/d period rich burials, with D-Ware, continue at these sites. But with fewer graves it is assumed that elite settlement moved near or on to the floodplain at this point (Patch 1991; Wilkinson 1999 and most Egyptologists studying this period, contrary to the case presented here). Conditions and land use for agriculture may usefully be compared to those in the Omo Valley and Senegal Chari-Logone in the early twentieth century (Butzer 1976). After the late summer/autumn floods receded crops were sown so they grew without major irrigation in the rainless winter months. Grazing was possible on the alluvial flats and from sub-desert vegetation, and fowl available in the backswamps. Here, and in Egypt before the construction of the Aswan high dam, settlements were concentrated on levees and the immediate riverbanks. During the inundation many would have been cut off and only accessible by boat unless linked to dry land by a causeway. In smaller scale, villages on the floodplain would have looked something like 1930s Assyut (Fig. 8). Therefore, it is likely that settlements were on the floodplain from the beginning and that the low desert sites represent elite ceremonial administrative and burial places rather than farming villages or towns.

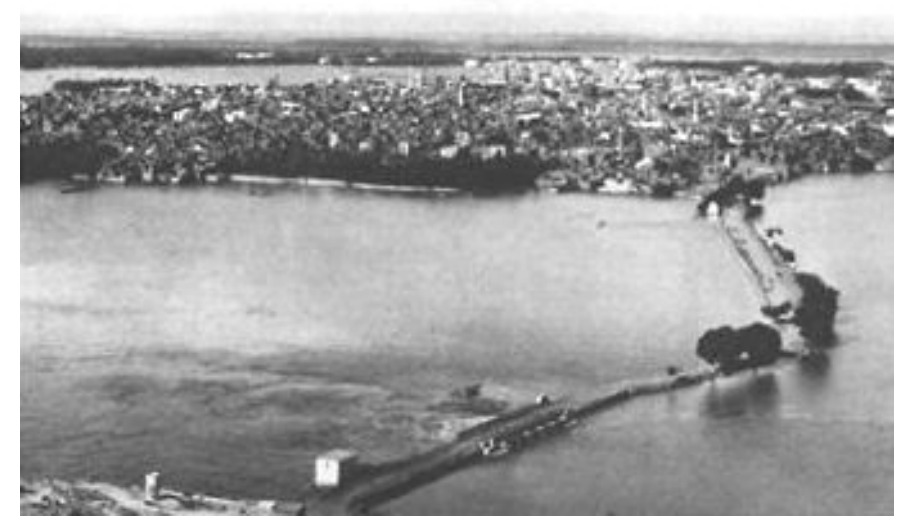

Fig. 7. Assyut in the inundation pre-Aswan high dam: an example of how floodplain settlements generally would have looked in the pre-modern period Source: Kemp 1989 


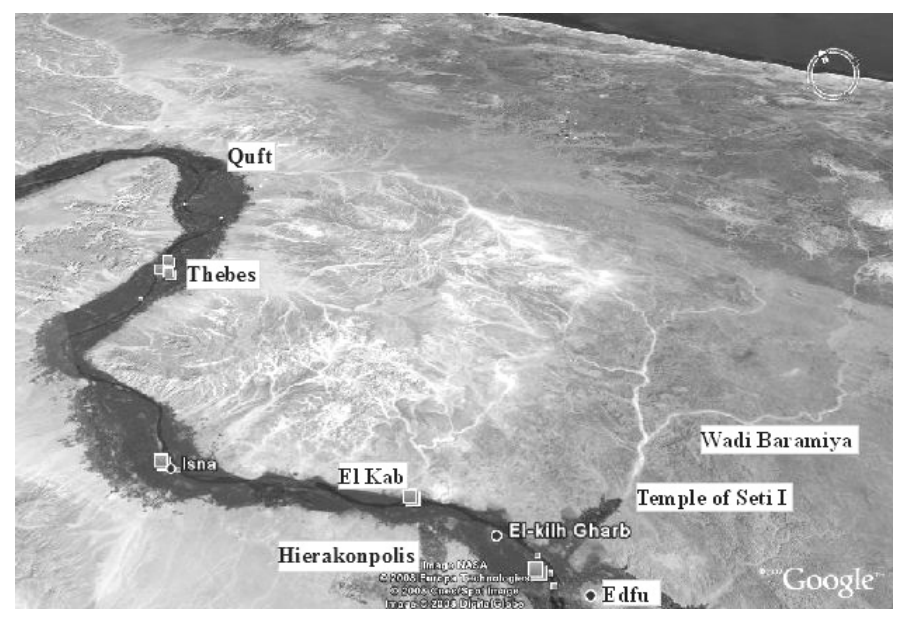

Fig. 8. Upper Egypt showing its constricted area,

Google Earth - not only is the cultivation much wider than in the Predynastic and Pharaonic Periods due to reclamation but the tongue of green reaching along the Wadi Abbad towards the rock-cut temple of Seti I did not exist twenty years ago

\section{EVIDENCE FOR/AGAINST POPULATION PRESSURE}

Using soil fertility, crop yield and calorific intake Butzer (1976: 85) proposed a population of approximately 1.5 million at the peak of the Old Kingdom with a growth rate of 0.8 per thousand, suggesting a quadrupling over the previous 1,500 years and a figure of around 250300,000 , mostly in Upper Egypt, for Naqada I (Fig. 9). But these are basically guestimates based on the floodplain's productive capacity and look considerably too high given that the allegedly mainly pastoralist population previous to and during the Badarian period is likely to have been low. Until recently, excavation has been mainly in the area from Abydos to Aswan and Delta archaeology is concentrated in the north-east. Although it is often assumed that the north-western Delta was sparsely occupied, little work has been done there. Buto looks suspiciously isolated without a hinterland, which would have existed in the Predynastic, and prehistoric remains have been located at Sais. There was probably a considerable Lower Egyptian Delta population comparable to that of Upper Egypt but the state arose in the South, not in the North. 


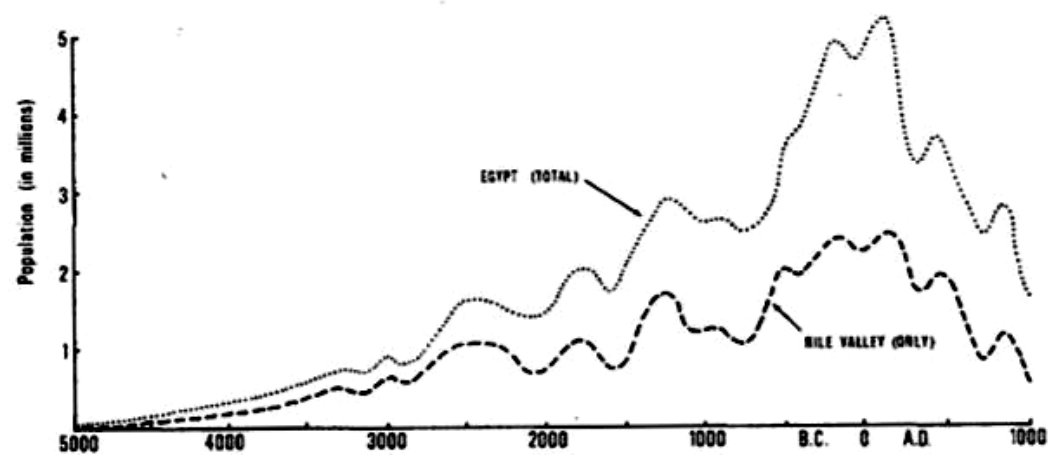

Fig. 9. Hypothetical population estimates, 5000 BC-1000 AD Source: Butzer 1976: 85

Evidence for population pressure in Ancient Egypt is lacking. The Nile Valley's agricultural capacity was comfortably sufficient to support the larger Old Kingdom population and flood recession agriculture is extremely productive without hydraulic works. There appears no reason why the situation in the Predynastic should have been different. On the other hand, Carneiro (2012b: 134) suggests that the picture of sparse population presented by Egyptologists is misleading. He proposes that the later nomes/provinces were originally predynastic warring chiefdoms and that population within these was tightly packed. This led to fighting between the nomes, creating buffer zones between them. However, we must remember that the nomes are an administrative feature of the Old Kingdom rather than of earlier periods. In the preceding Early Dynastic period administration was probably carried out through a combination of tightly controlled 'domains' and 'estates' to extract resources for the royal court and mortuary cult, a royal progress: the 'Following of Horus,' and a light-touch overall policy using local headmen and ad hoc missions from the centre (Moreno-Garcia 2014). We have also seen that the perception of sparsely occupied areas of Upper Egypt is based on a misreading of cemeteries as a) containing a cross-section of the population and b) low desert sites being agricultural villages or towns. Therefore, these buffer zones are unlikely to have existed. On the contrary, the floodplain population distribution would have been determined by where suitable high protective levees were located and also by knowledge of the best land and soil quality.

The 'Circumscription Theory' maintains that tight environmental constriction produced population pressure, which in turn brought about recurring warfare culminating, in certain areas, in the rise of the state (Carneiro 1970). This has recently been reformulated to put less 
emphasis on environmental circumscription as an initiator and more emphasis on force as the means by which several villages were originally united, since 'No political unit, regardless of its size... ever gave up its sovereignty of its own accord' (Carneiro 2012a: 10). Egypt comprises a long river tube surrounded by deserts which kept people in. Resource concentration, present in the inundation as 'the gift of the Nile' but also through the availability of wild fowl and ability to graze large herds of cattle, would increase numbers of people as a resource for the ruler and then lead to population pressure. Carneiro has also consistently maintained that there is no example of a historically or ethnographically known chiefdom or state arising without warfare playing a major role at some stage and that population pressure plays a major role in provoking it. Significantly, he has consistently excluded ideology as a primary cause by stating that 'ideas are not uncaused causes' (Carneiro 2002: 96) with Kurtz (2004: 150) noting that 'the role of the individual agent as an energetic force in political evolution also is unpopular with anthropologists.'

Both warfare and population as factors have been challenged with Claessen $(2012,2016)$ stressing ideology and Gibson (2012) status rivalry, supporting Kemp's (1989) view, long-standing among Egyptologists, that so-called 'aggrandizers' (Castillos 2014) were crucial in Egyptian state formation. Egypt was the world's first pristine unitary state and we have abundant evidence of an elite ideology based on control of wild natural forces from very early in Naqada I, the period of established sedentism and the first elite centres. Claessen (2016) proposes a Complex Interaction Model in which ideology plays a primary role and warfare and conquest are not independent factors for the emergence of pristine states. Rather, developments are usually peaceful and gradual, although coercion is also utilised. Elites emerge who control the economy of a society whose format is changed by cultivating more land and where increasing population and area require changes in administrative/political structure in which elites gain and support their control through sacred power. Each change elicits responses which trigger more changes which in turn require other responses from leaders and so on by which they exercise hegemony, persuading the general populace that their leadership, and its reward, is both natural and divinely inspired (Kurtz 2004, 2011). It is therefore necessary to examine the archaeological evidence for warfare and conquest, even if evidence for population pressure is slim in the admittedly geographically circumscribed zone of Predynastic Upper Egypt, and how elites could effectively exercise control using both a measure of coercion and ideology. 


\section{EVIDENCE FOR AND AGAINST CONFLICT}

\section{Iconography}

Naqada I disc-headed maces are found in graves, without appearing to be practical weapons, but more akin to sceptres. An iconography of warfare including 'victory scenes' with 'bound prisoners' has been proposed on C-Ware (Hendrickx 2011 in favour of victory scenes contra Garfinkel 2001 against). On the Abydos Tomb U-239 pot (Fig. 10) a large figure holds what might be a mace, but in a non-threatening way. Nor are the smaller figures bound. They hold each other's hands and at the bottom a woman carries a small child. The lines from the smaller figures' shoulders on the Brussels pot (Fig. 11) represent arms poorly applied to the surface rather than bindings. The U-145 pot from Abydos (Fig. 12) shows the arms crudely depicted in both the top and middle register figures, standing arm-in-arm rather than being bound. Significantly, the feather-wearing figures harpooning hippopotami have limbs similarly crudely depicted. We might conclude that elite families are represented here, not captor and prisoners.

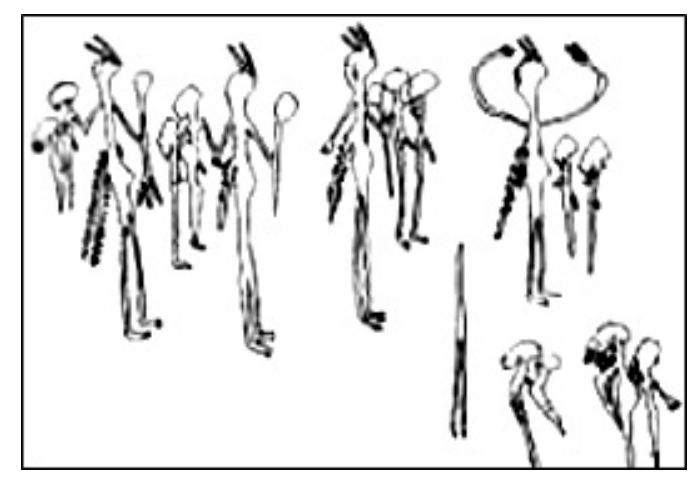

Fig. 10. U-239 C-Ware

Source: Garfinkel 2001: 244 


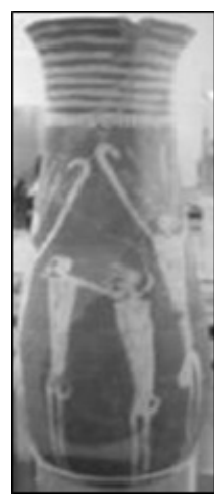

Fig. 11. Royal Museum of Arts \& History, Brussels Source: author's photo C-Ware

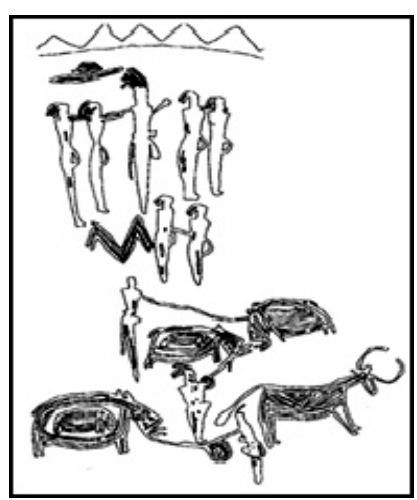

Fig.12 U-145 C-Ware Source: Graff 2009: 247

Pear-shaped mace-heads appear in burials in Naqada II, and there is one representation from Naqada IIc Hierakonpolis Tomb 100 (Fig. 13) usually interpreted as a 'smiting scene,' where a mace-bearing figure stands over three 'prisoners.' However, their arms do not appear to be bound and the larger figure holds the club-like 'mace' oddly at the very bottom of the handle. He could as well be the men's commander as their captor. Even if we accept this as a representation of violence, during Naqada IId there is a limited array of artefacts that may display violence: a knife handle from Abydos Tomb U-127 (Fig. 14), the Gebel el Arak knife handle (Fig. 15), and the Gebel Tjauti 'Scorpion' rock-art tableau (Fig. 16), although this may be dated later to Naqada III (dated to Naqada III by Darnell (2002) and to Naqada IId by Hartung (2006) - on an iconographic basis I prefer Darnell's dating). All three show prisoners, but whether these are Upper Egyptians engaged in internal warfare to subdue predynastic polities as argued by Carneiro is problematic. The U-127 figures could represent people from the Faiyum/Delta or Asiatics, who are difficult to differentiate in this early period's iconography. Other knife handle fragments from U-127 have ordered lines of wild animals (Dreyer 2008), often interpreted by Egyptologists as symbolic of 'the triumph of order over chaos' constituting the dominating iconography of the elites.

The Gebel el Arak knife handle (Fig. 15, Naqada IId) demonstrates how we cannot assume actual events are presented. In the two upper registers of the battle scene the fighters with short hair appear to 
be winning over the long-haired ones, while in the sea battle register it is the short-haired figures which are corpses in the water. The other side of the handle has animal control scenes. Moreover, although the ivory is damaged, the figure with a leash on the 'battle' side is connected by it to the animals on the reverse suggesting the theme of control and domination of the whole of the natural order: humans and wild creatures. Any connection to the earlier Naqada I C-Ware scenes is to the U-145 pot with its hunting scene and 36 other examples on C-Ware (Graff 2009). There is a similar animal control scene on the muchabraded Abydos tomb 503 knife handle to the Gebel el Arak knife (Fig. 17). Altogether, concerning the Naqada IIc-d material we have a very small number of scenes of domination and control, but no firm proof that these represent inter-chiefdom conflict. Evidence for conflict from this period or Naqada I rests on extremely limited iconographic evidence. The extremely circumscribed and small area of Upper Egypt could anyway have made any military action quite brief. There was no high ground to which threatened polities could retreat and fortify as in cases such as the Oaxaca Valley (Marcus 2012). Without fortification smaller polities would have been easily overcome by larger ones or they could have been overawed and succumbed to threats without resistance.

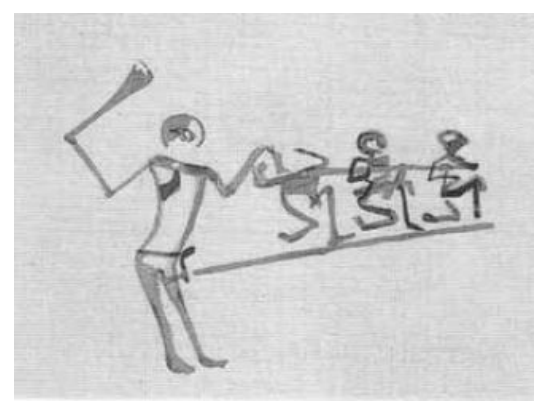

Fig. 13. Detail from Tomb 100, Naqada II, Hierakonpolis, from Petrie Museum poster of original watercolour in author's possession

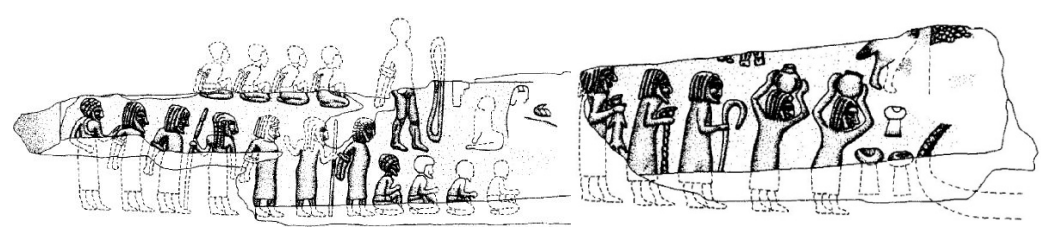

Fig. 14. Knife handle, U-127, Abydos Source: Dreyer 1998 

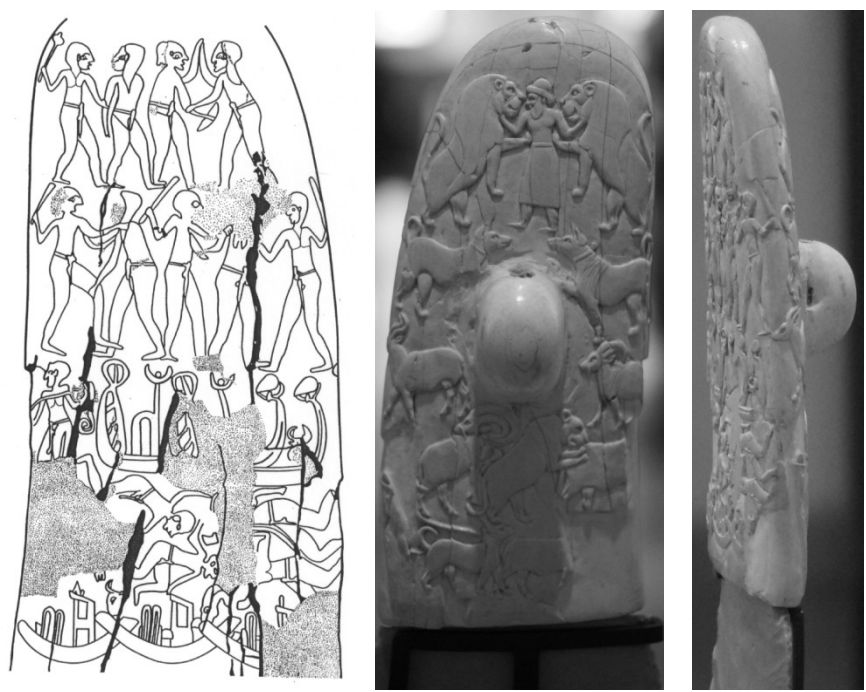

Fig. 15. Gebel Arak knife handle

Source: Mark 1987 and Louvre, author's photos

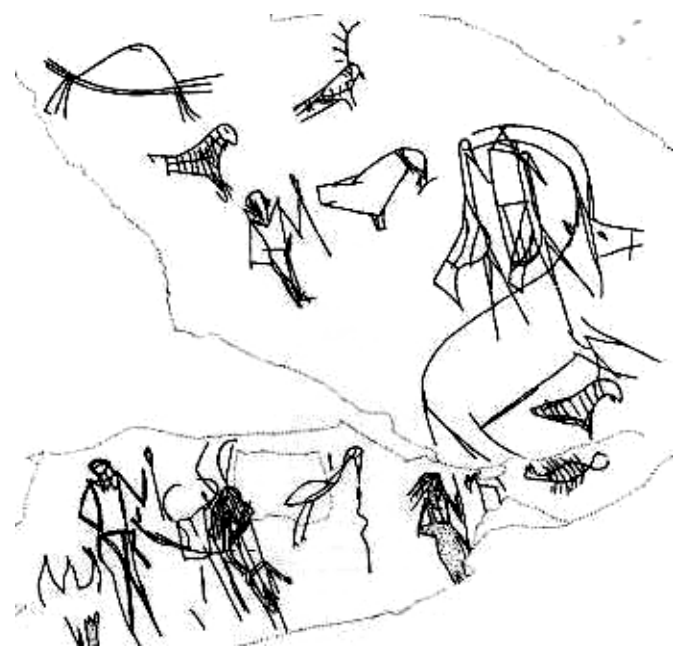

Fig. 16. 'Scorpion Tableau', Gebel Tjauti, desert west of Thebes, Source: Darnell 2002 

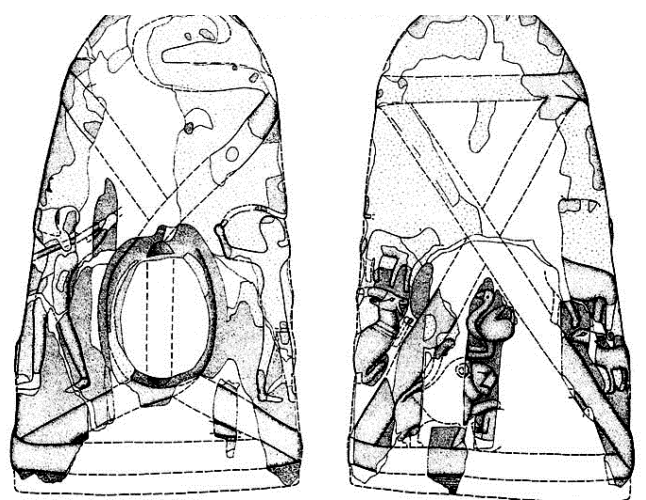

Fig. 17. Knife handle obverse and reverse, Tomb U-503, Abydos Source: Raffaele N.d.

\section{Walls}

If the Nile Valley village communities were united by conflict, we would expect to see walled fortifications and settlements, especially given the relatively small area of Upper Egypt. The ease with which enemy forces could attack by boat and via desert tracks made any settlement along the whole length of river vulnerable. However, there is no evidence of walls or fortification surrounding any pre-dynastic site, whereas in the First Intermediate Period following the end of the Old Kingdom there was both warfare and fortifications in the process of rebuilding a united Egypt from a fragmentary situation. The walled area at Naqada covers a very limited elite area, while mudbrick walls at Abydos and the dynastic floodplain site of Nekhen are assigned much later to the Second Dynasty (Kemp 1977). No other site where evidence for elites has been found, for example, Mahasna, $\mathrm{Hu}$ and Gebelein, show any trace of fortification. Whether or not the floodplain villages were surrounded by dykes, it would be a strange military situation where settlements were protected and elite centres were not. This alone speaks against military conflict.

There are no images of walls until the 'Towns/Libyan' (Fig. 18) and 'Bull' Palettes (Fig. 19). Stylistic similarities: the detail around the eyes, register lines and wild animals probably representing the same ruler as on the Narmer Palette, date both objects to the very early First Dynasty (ca. $3150 \mathrm{BC}$ ). Significantly, they are the first possible representations of walls since the beginning of the Naqada cultural phase approximately 600 years previously. The only undoubted walled settlement dates from Naqada IIIb, just before or during Narmer's reign, at the outpost of Tel es Sakan in Gaza (Miroschedji 
2001). Therefore, either the niched elements on the palette are not towns or they are not in Egypt. There were no Canaanite cities until after the Egyptian withdrawal from the area which probably took place in the middle of the First Dynasty, and there were none in Libya (Braun 2011). We do have niched enclosures on labels and sealings from the Early Dynastic period. A hoe by a 'toothed' oval may represent founding an estate (Fig. 20, Monnier 2013: 254, from Abydos and suggested to be First Dynasty). A King Den label shows a temple also surrounded by a niched wall (Figure 21) and the Palermo Stone has niched representations with names such as 'Companion/Thrones of the Gods' which are probably temples (Wilkinson 2000). So the niched images are almost certainly not towns. This suggests, and only from the Early Dynastic period not the Predynastic, that a wall enclosed a royal establishment of some kind.

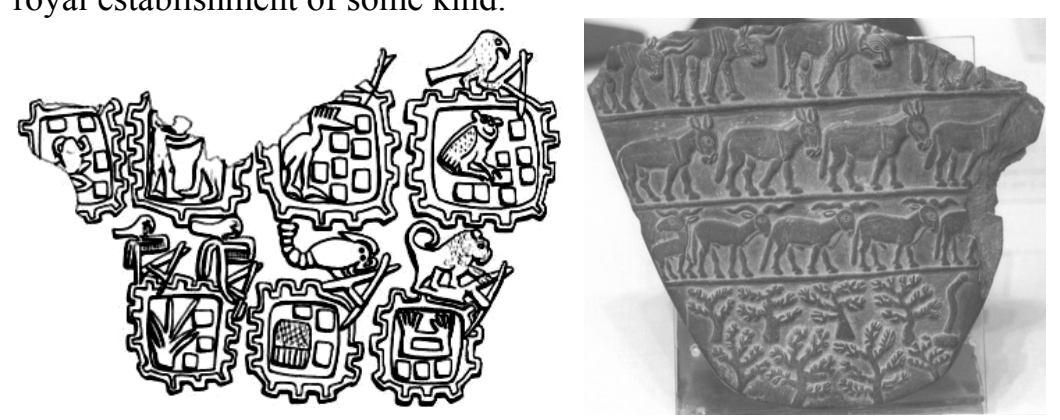

Fig. 18. 'Towns' or 'Libyan' Pallette,

Source: Monnier 2013: 244, and author's photo, Cairo Museum

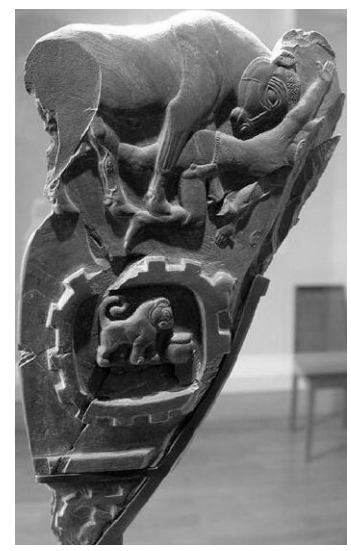

Fig. 19. 'Bull' Palette

Source: Louvre Museum, author's photo 


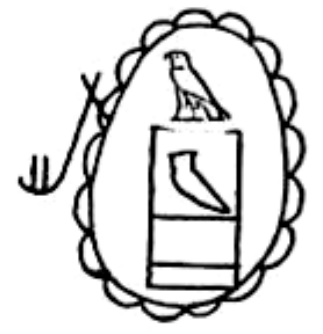

Fig. 20. 'Estate' foundation Source: Monnier 2013

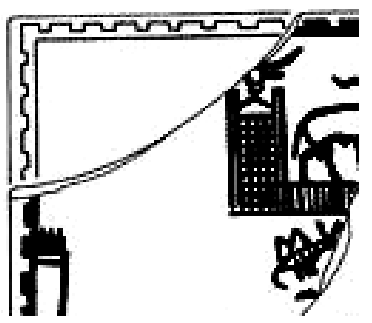

Fig. 21. Label showing temple enclosure

Source: Wilkinson 1999

\section{SOCIAL RANKING: PRODUCTION AND REINFORCEMENT}

Neither violence nor urbanization appears as factors producing social ranking and polito-genesis. Then how was the Egyptian state formed without the urban environment breaking down kinship ties and conflict melding local polities together? Moreover, why did farming villages not always continue in equilibrium with each other and, given Carneiro's dictum, why would they surrender their autonomy? Modelling suggests that given environmental stability social complexity in farming villages is extremely unlikely to arise (Scott N.d.). However, Hassan (1988: 168) has suggested that, "the apparent uniformity of the Nile Valley is a cartographic illusion' since the area of cultivatable land available annually to each village varied with the flood. Different Nile heights year by year which selectively broke levees, and variable siltation, meant that the apparently timeless and uniform inundation in reality affected communities differently. Someone had to decide the time for planting, and how the land was to be partitioned and dykes maintained. It might be the village headman who made this decision rather than a communal group of elders. Performing a useful function in mediating between potentially disruptive claimants to land, he merited a reward and the task of reallocating land left room for favouritism. A 'first fruits' ceremony offering out of respect to the head-man at harvest time may have developed over time into paying tribute. The leaders' authority could also be reinforced by magical and religious power, including the ability to contact the ancestors to solve problems in the community while reinforcing legitimacy and dealing with malcontents. However, if the agricultural land was held collectively by lineages and reallocated annually hierarchically, this would also pro- 
duce elite figures. We have already seen that there was probably social inequality in the pre-sedentary phase. The scenes of dominance over the wild on pottery and in rock-art scenes evidence the presence of elite aggrandizers from an early stage of the Predynastic.

The elite iconography, both on objects (especially pottery) from burials and the rock-art, is very similar over the whole of the Naqadan cultural core of Upper Egypt from Abydos in the north to Egypt in the south. This suggests a common ideology as a basis of competition for political power and its reinforcement once gained. In support of Carneiro, Hakami (2012: 59) maintains that 'ideas are the effect of material circumstances and chiefdoms are truly not the product of an idea,' but qualifies this by maintaining that ideology plays an important and constitutive role 'given that a specific political ideology serves as a necessary function of structural and infrastructural components of a given system.' It is therefore a fruitless task to ask which of these comes first. Moreover, superstructural elements can spread very fast as less developed societies borrow from more developed ones, this only making sense if these political ideologies come before political structures are established, 'because the establishment of political structures is the very reason the former have been imported' (Hakami 2012: 59). We can observe that a dozen elite centres appear very close in time to each other in Naqada I with the same ideological raison d'être of control over the wild undisciplined forces which surrounded the thin and constricted cultivation (settlement zone) and near desert area (elite architecture zone) of the Upper Egyptian Nile Valley. It is impossible to know where this ideological construction originated as the earliest monumental architecture and subsidiary animal burials are at Hierakonpolis, while C-Ware depictions related to, but not exactly the same as the rock-art, are found from around the same time at Abydos.

Basin agriculture was practised in the Egyptian historic period when we know that there was a high degree of interdependence locally based on an area served by a particular canal. But between the canals local communities were autonomous, calling in an arbiter to settle differences according to village custom and law (Kahn 2006: 35). There was no need for an overall regional utilitarian leader and disputes were contained at a local level. But if there was social stratification from a very early stage in the Predynastic, the elites possessed a significant advantage because of Egypt's geography. It is only 250 kilometres from Abydos, later the burial ground for the First Dynasty kings, in the north of the core of the Upper Egyptian Naqada Culture to Hierakonpolis, its main political centre in the south. Upper 
Egypt's relatively small area, combined with the tubular effect of the Nile and its blocking surrounding deserts, created transparency (Mayshar et al. 2011). The village peasants could not conceal the extent of their farming success, since the Nile inundation height could be calculated and the extent of cultivation easily observed. The annual record of Nile heights on the Palermo Stone (Wilkinson 1999) shows its importance in the pharaonic era and would have been vital to predynastic rulers too. A small group of enforcers by boat and on land could have recorded and policed this to extract taxation. Living close to the river, and hemmed in by the unforgiving desert, dissatisfied villagers could not leave. The effect of the tube and constriction of area combined with local basin agriculture made administration and enforcement easy. Each headman could be given a quota with the stick of the threat of replacement on failure to deliver, without the need to offer a carrot of reward much more than maintaining his position.

\section{TOWARDS STATEHOOD}

During Naqada II and III, Upper and Lower Egypt grew together and increasing Upper Egyptian influence, perhaps through settlers and traders, can be seen in the north-eastern Delta on the routes to Canaan and Asia (Guyot 2008). Moreover, in Naqada III not merely the practice of burying considerable numbers of grave goods but also corpse orientation in Lower Egypt gradually became like Upper Egyptian practice (Savage 2001). This fundamental change would only have occurred if there was a strong Upper Egyptian presence, or local leaderships saw some benefit to acculturation. However, the idea that this need to have resulted from Abydos, with its alleged superior trade connections to Asia, 'conquering' Naqada and other areas must be questioned. Both Naqada and Hierakonpolis had access to many resources necessary to construct 'powerfacts' from the Eastern Desert. Naqada could acquire items like gold, siltstone for palettes (which could have been made from material near at hand), carnelian, ostrich shells, and seashells. By virtue of its geographical position, Hierakonpolis also had access to the matching exotics of Nubia, which had additional prestige by virtue of being acquired from strange lands at a distance. The ability of elites at Abydos, Naqada and Hierakonpolis to obtain goods from faraway lands may have allowed them to attract more retainers than at other polities such as Gebelein. This was an elite centre in Naqada II as shown on the Gebelein Linen with its scenes of boats and domination of wild animals reminiscent of the rock-art. Related scenes are also found on the Tomb 100 painting at Hierakonpolis (Raffaele N.d). Gebelein and other chiefdoms, compressed between Abydos and Hi- 
erakonpolis, which were probably unable to grow large enough to compete and would also have been blocked from engaging in longdistance trade. Alliance by marriage may have led to polities coalescing and although the first Egyptian kings are buried at Abydos, Hierakonpolis appears to have had an honoured place into the Early Dynastic period (Friedman 2011).

In Naqada IIIA1 (approximately 3300 BC) the multi-chambered Tomb U-j with at least 400 Canaanite vessels, many with traces of wine, indicates a powerful ruler at Abydos with at least exchange contacts to the Delta (Dreyer 1998). The first writing is found on 170 bone labels which were probably originally attached to grave goods in this tomb. Place names from Upper Egypt as far south as Aswan and the Delta, including Elephantine, Buto and Bubastis, have been proposed (Jimenez-Serrano 2007). These provide evidence for a bureaucracy and specialised administration. There is little further evidence of a systematic system of writing until the reign of Iry Hor, two kings before Narmer, but this may be due to artefact survival or a temporary decline in the power of the early Upper Egyptian state. Vessels inscribed with 'produce of Lower Egypt' and 'produce of Upper Egypt' show this administrative division of the country at least two reigns before complete 'unification' by Narmer, the first king of the First Dynasty (Lanna 2008). A number of serekhs (niched facade frames, later topped by a falcon, containing the ruler's name/title although earlier examples are blank) may represent independent Delta rulers before Narmer which were created on the periphery of the Upper Egyptian state and adopted its iconography of rulership (Jimenez-Serrano 2003). The process by which any Lower Egyptian polities were absorbed by Upper Egypt is as obscure as that by which the latter was united. But the Abydos polity must have had the power to insist on the passage of expeditions into Sinai to the turquoise mines since emblems of Iry Hor and Ka, the two rulers before Narmer who are buried in Abydos cemetery B in graves near his, are inscribed on the rocks in Wadi Maghara there (Tallet and Laisney 2012). Thus, there was an Upper Egyptian state before unification and before the reign of Narmer, ostensibly the first king of Dynasty I. Given that Iry Hor (probably meaning 'pertaining to Horus') is actually the first 'Horus King' buried in the royal cemetery, it appears that Narmer's casting as a founder of the First Dynasty was a political claim within the state's royal family either at the time or retrospectively. An attempt to restore the previously held view that the Narmer Palette shows the creation of the Egyptian state at this late date when surplus labour may have become available due to a wide- 
spread inundation of the Delta (Proussakov 2004) is thereby refuted, whether there was an environmental crisis or not. The state (Naqada IIIa) preceded unification (Naqada IIIb) and the Scorpion and Narmer Maceheads, Narmer, Bull and Libyan Palettes mark its aggressive expansion not its foundation.

Why then did not a complete unification of Upper Egypt and the Delta into one nation take place until approximately 150 years later than the rule of Tomb U-j's owner which marks emergence of the state? Inherent military probability suggests that although an army of even 1,000 men would have been a formidable raiding force, it could not garrison and hold down the Delta against a potentially hostile population. The campaigning season would have been limited in that it excluded the height of summer, and also planting and harvest times. The Nile constituted a highway by boat, but contrary winds, shoals and the inundation in full flood were obstacles to an armada. Moreover, the number of Delta channels and expanses of marshland made it easy for an invader unfamiliar to the area to get lost once away from the main branches of the Nile due to the lack of landmarks. This is in contrast to Nubia where the Gebel Sheikh Suleiman graffito marks the crushing of the A-Group polities of Sayala and Qustul, (probably in the early First Dynasty), since the Egyptians could sail along one narrow easy channel. Before the establishment of Upper Egyptian populations as settlers or traders in the North at sites such as Tel El Farkha and Minshat Abu Omar in the North-eastern Delta on the route to Sinai and Canaan' the Upper Egyptians would have had little knowledge of the Delta and no potential centres of support to find sympathisers and allies. In addition, the probably decentralised nature of authority in Lower Egypt meant it was not possible to defeat or co-opt a single chieftain and thus gain control of significant territory until the final stage when the Narmer Palette may represent defeat of the last independent Lower Egyptian polity. First, Tarkhan was established in a position where the Nile debouches into the Delta to be the main Upper Egyptian staging post and expeditions were launched into the turquoise area of Sinai. Later, the main administrative centre was moved even further forward to Memphis: the 'Balance of the Two Lands.' It is from the time of Narmer onwards that we see a number of scenes of violence: lines of bound prisoners, rows of headless corpses, the ruler as a bull goring an enemy, and the 'smiting scene' on ivory tablets in the Ashmolean Museum, Oxford, and on the Narmer and Bull Palettes. These may represent a real conquest of at least parts of the Delta by force. Thus, Egypt's unification took place a considerable 
period after the appearance of the state and represents the expansion of the Upper Egyptian state into Lower Egypt.

\section{EGYPT AS A 'RURAL PETTY STATE'}

Early state formation is often an obscure process, perhaps inherently so, since it is a pre or proto-historic process that becomes hidden once the state is formed and entrenched. In a number of cases, including the Andes, China and Egypt, the large territorial state formed not from urban nuclei but out of small political units, here called the 'rural petty state' (Gat 2003). This differs from the urban-centred petty state which is commonly referred to as a 'city state.' The Anglo-Saxon polities in the sixth-ninth centuries AD achieved the level of advanced states but were essentially rural, not developing significant urban components until the tenth century (Hodges 2001). Well-known Saxon villages such as Wharram Percy were not nucleated and arranged along a main street until the ninth century $\mathrm{AD}$ and thus post-dated the state rather than being a factor in its formation (Blair 2014). The "typical' Anglo-Saxon hamlet consisted of approximately 25 adults and the next settlement up was the royal centre, itself focused on a great hall and of no great size (Hodges 2001). Early Anglo-Saxon villages consisted of a few houses and gardens. An elite centre was also a relatively small settlement, although it contained impressive wooden buildings which were probably elaborately carved to demonstrate their status, comparable to the situation in early Egypt. In first-century AD southern Britain 'territorial oppida' operated as a kingdom's central place with elite residences, monumental architecture (ramparts, but with large spaces between the dykes indicating their purpose was display rather than defence), shrines and evidence of feasting, but without a significant population (Darvill 2010). The San Dai centre of elite/public buildings and prolific craft activity was divided into spatially separated districts more like 'fundamentally distinct villages' with dispersed palace, temple, tombs, workshops and servitor housing than a nucleated urban centre (Maisels 1999). Other petty polities which developed later into larger more complex political entities include the Franks, the princedoms of Rus, Yayoi (first and second centuries BC) and Yamatai (third century BC) in Japan (Gat 2003). Over time these tended to coalesce due to size giving a competitive advantage in power politics, but originally they were small polities based on a palace or citadel.

This model involves regional rulers and elites submitting to a political centre through the exercise of both coercion and co-option. Often 
overlordship made administration easier by working through local elites largely left in place, or they could be removed. Egypt was built up from small units into a large territorial state, the first in history. The consolidation of elite centres suggests that in the case of Egypt local elites either moved to the court or were proactively removed, with power being concentrated in the hands of one family and one man designated 'the Living Horus' in Naqada III (Patch 1991; Castillos 2014). Therefore, there is an alternative to an urban model of polito-genesis and state formation into which the Egyptian evidence sits comfortably. Moreover, it is one in which Egypt's geography created transparency leading to ease of coercion and minimum necessary use of force in controlling the mass of the population. Contrary to a general resistance among anthropologists in acknowledging the importance of ideology, it played a considerable part both in the construction and maintenance of Egyptian elites. Finally, in the initial process of polity formation and in building the Egyptian state evidence for warfare is extremely limited and for population pressure there is none.

\section{REFERENCES}

Anderson, D. A. 2006. Power and Competition in the Upper Egyptian Predynastic-A View from the Predynastic Settlement at el Mahasna, Egypt. Unpublished $\mathrm{PhD}$ thesis, University of Pittsburgh.

Anderson, W. 1992. Badarian Burials: Evidence of Social Inequality in Middle Egypt during the Early Predynastic Era. Journal of the American Research Center in Egypt 29: 51-66.

Blair, J. 2014. In Search of the Origins of the English Village. Current Archaeology 291: 12-22.

Braun, E. 2011. Early Interaction Between Peoples of the Nile Valley and the Southern Levant. In Teeter, E. (ed.), Before the Pyramids: The Origins of Egyptian Civilisation (pp. 105-122). Chicago:.

Brooks, N. 2004. Beyond Collapse: The Role of Desication in the Emergence of Complex Societies in the Middle Holocene. In Leroy, S., and Costa, P. (eds.), Environmental Catastrophes in Mauritania, the Desert and the Coast, Abstract Volume and Field Guide (pp. 26-30). Mauritania, First Joint Meeting of ICSU Dark Nature and IGCP.

Butzer, K. 1976. Early Hydraulic Civilisation. Chicago.

Carneiro, R. 1970. A Theory of the State. Science 169: 733-738.

Carneiro, R. 2002. Was the Chiefdom a Congelation of Ideas? Social Evolution and History 1 (1): 80-100.

Carneiro, R. 2012a. The Circumscription Theory: A Clarification, Amplification, and Reformulation. Social Evolution \& History 11 (2): 5-30. 
Carneiro, R. 2012b. Answers to Critiques. Social Evolution \& History 11 (2): 131-190.

Castillos, J. J. 2014. Migration of Elites in Early Egypt. URL: https://www. academia.edu/6288472/Migration_of_elites_in_early_Egypt_to_be_publi shed_in_RSUE_32_2015.

Claessen, H. J. M. 2012. Reconsideration of a Reformulation. Social Evolution and History 11 (2): 36-43.

Claessen, H. J. M. 2016. The Emergence of Pristine States. Social Evolution and History 15 (1): 3-57.

Darnell, J. C. 2002. Theban Desert Road Survey in the Egyptian Western Desert. Chicago: Oriental Institute Publications.

Darvill, T. 2010. Prehistoric Britain. London: Routledge.

Dee, M., Wengrow, D., Shortland, A. Stevenson, A., Brock, F., Flink, L. G., and Ramsey, C. B. 2013. An Absolute Chronology for Early Egypt Using Radiocarbon Dating \& Bayesian Statistical Modelling. Proceedings of the Royal Society. URL: rspa.royalsociety publishing.org.

Dreyer, G. 1998. Umm el-Qaab I, Das prädynastische Königsgrab U-j und seine frühen Schriftzeugnisse. Mainz, Germany.

Friedman, R. F. 2011. Hierakonpolis. In Teeter, E. (ed.), Before the Pyramids: The Origins of Egyptian Civilisation. Chicago.

Fuchs, G. 1991. Petroglyphs in the Eastern Desert of Egypt: New Finds in the Wadi Baramiya. Sahara 4: 59-70.

Garfinkel, Y. 2001. Dancing or Fighting? A Recently Discovered Predynastic Scene from Abydos, Egypt. Cambridge Archaeological Journal 11 (2): 242-254.

Garwood, P. 2011. Van Gennep's Ritual Process - An Anthropological Classic and its Archaeological Heritage. In Insoll, T. (ed.), The Oxford Handbook of the Archaeology of Ritual \& Religion. Oxford.

Gat, A. 2003. Rural Petty-State and Overlordship-Missing Links in the Evolution of the Early State. Anthropos 98: 127-143.

Gibson, D. B. 2012. Carneiro's Social Circumscription Theory: Necessary but not Sufficient. Social Evolution and History 11 (2): 51-55.

Graff, W. 2009. Les Peintures sur Vases de Naqada I-II: Nouvelle Approche Séminologique de l'Iconographie Prédynastique. Leuven.

Guyot, F. 2008. The Origins of the 'Naqada Expansion' and the Interregional Exchange Mechanisms Between Lower Nubia, Upper and Lower Egypt, South Levant and North Syria during the First Half of the 4th millennium. In Midant-Reynes, B., and Tristant, Y. (eds.), Egypt at its Origins 2 (pp. 707-740). Leuven.

Hakami, K. 2012. Questions to Spencer's Bulldog. Social Evolution and History 11 (2): 58-62. 
Hamilakis, Y. 2003. The Sacred Geography of Hunting: Wild Animals, Social Power, and Gender in Early Farming Societies. In Kotjabopoulou, E., Hamilakis, Y., Halstead, P., Gamble, C., and Elefanti, P. (eds.), Zooarchaeology in Greece: Recent Advances. London.

Harlan, J. F. 1985. Predynastic Settlement Patterns: A View from Hierakonpolis. Unpublished doctoral thesis. University of St. Louis, Missouri.

Hartmann, R. 2008. Zwei Fragmenten der White Crossed Lined Ware aus dem Friedhof $U$ in Abydos zu Gefäben aus dem Ägyptische Museum Kairo. In Engel, E., Müller, V., and Hartung, U. (eds.), Zeichen aus dem Sand (pp. 163-182). Wiesbaden.

Hartmann, R. 2011. The Chronology of Naqada I Tombs at Abydos. In Friedman, R. F., and Fiske, P. Egypt at its Origins 3. London.

Hartung, U. 2006. Some Remarks on a Rock Drawing from Gebel Tjauti. In Kroeper, K., Chlodniki, M., and Kobisiewicz, M. (eds.), Archaeology of North-Eastern Africa. Poznan.

Hassan, F. 1988. The Predynastic of Egypt. Journal of World Prehistory 2 (2): 135-185.

Hendrickx, S. 2011. Iconography of the Predynastic and Early Dynastic Periods. In Teeter, E. (ed.), Before the Pyramids: The Origins of Egyptian Civilisation (pp. 75-81). Chicago.

Hodges, R. 2001. Dark Age Economics: The Origins of Towns and Trades AD 600-1000, Eastbourne, UK.

Hoffman, M. 1982. The Predynastic of Hierakonpolis-An Interim Report, Cairo.

Hoffman, M. 1987a. Egypt Before the Pharaohs. London.

Hoffman, M. 1987b. A Regional Perspective of the Predynastic Cemeteries of Hierakonpolis. In Adams, B. (ed.), The Fort Cemetery at Hierakonpolis (pp. 187-203). London.

Jimenez-Serrano, A. 2003. Chronology And Local Traditions: The Representation Of Power And The Royal Name In The Late Predynastic Period. Archeo-Nil 13: 93-142.

Jimenez-Serrano, A. 2007. Principles of the Oldest Egyptian Writing. Lingua Aegyptia 15: 47-6.

Kahn, M. 2006. Hidden Pharaohs: Egypt, Engineers and the Modern Hydraulic. Unpublished MPhil thesis. Trinity College, Oxford.

Kemp, B. 1977. The Early Development of Towns in Egypt. Antiquity 51: 185-200.

Kemp, B. 1989. Ancient Egypt-Anatomy of a Civilisation. Abingdon.

Kuper, R., and Krőplin, S. 2006. Climate-Controlled Holocene Occupation in the Sahara: Motor of Africa's Evolution. Science 313: 803-807.

Kurtz, D. V. 2004. The Evolution of Politics and the Transition from Political Status to Political Office. Social Evolution and History 3 (2): 150-175. 
Kurtz, D. V. 2011. The Evolution of Social Organisation. Social Evolution and History 10 (2): 3-48.

Lankester, F. D. 2013. Predynastic and Pharaonic Rock-art in Egypt's Central Eastern Desert: Distribution, Dating and Interpretation. Oxford.

Lanna, S. 2008. Lo Stato egiziano nelle fonti scritte del periodo tinita. Oxford.

Marcus, J. 2012. The Formation of Political Hierarchies and the Loss of Autonomy. Social Evolution and History 11 (2): 74-78.

Maisels, C. M. 1999. Early Civilisations of the Old World. New York.

Mark, S. 1987. From Egypt to Mesopotamia: A Study in Predynastic Trade Routes. Austin, USA.

Mayshar, J., Omer, M., and Neeman, Z. 2011. Transparency, Appropriability and the Early State. Centre for Economic Policy and Research Discussion Paper. URL: http://sticerd.lse.ac.uk/seminarpapers/dg17102011.pdf.

Midant-Reynes, B. 2000. The Prehistory of Egypt: From the First Egyptians to the First Pharaohs (translated by I. Shaw). Oxford.

Miroschedji, P. de, 2001. Les fouilles de Tell es-Sakan (Gaza): Nouvelles Données sur les Contacts Égypto-cananéens aux IVe-IIIe Millénaires. Paléorient 27 (2): 75-104.

Monnier, F. 2013. La Houe et la Forteresse: Finalement, Acte de Fondation ou de Destruction? ENiM 6: 243-256.

Moreno-Garcia, J. (ed.). 2014. Egyptian Administration. Leiden.

Newell, G. 2012. A Re-examination of the Relative Chronology and Socio/ economic Structures of the Badarian Culture Via an Algorithmic Seriation of its Ceramic and Slate Artifact Assemblages. URL: http://www. academia.edu/2095635/A_Re-examination_of_the_Badarian_Culture.

Park, T. K. 1992. Early Trends Toward Class Stratification: Chaos, Common Property, and Flood Recession Agriculture. American Anthropologist 94: 90-108.

Patch, D. C. 1991. The Origin and Early Development of Urbanism in Ancient Egypt: A Regional Study. Unpublished doctoral thesis. University of Pennsylvania, Philadelphia.

Proussakov, D. B. 2004. Early Predynastic Egypt: A Socio-Environmental/ Anthropological Hypothesis of 'Unification. In Grinin, L. E., Carneiro, R., Bondarenko, D. M., Kradin, N. N., and Koratayev, A. V. (eds.), The Early State: Its Alternatives and Analogues. Volgograd.

Raffaele, F. N.d. Late Predynastic \& Early Dynastic Egypt. URL: http://xoo mer.virgilio.it/francescoraf/index.htm.

Savage, S. H. 1995. Descent, Power and Co-operation in Predynastic Mortuary Evidence from Cemetery N7000 at Nag ed Deir. Unpublished doctoral thesis. Arizona State University. 
Savage, S. 2001. Some Recent Trends in the Archaeology of Predynastic Egypt. Journal of Archaeological Research 9: 101-155.

Scott, S. N. d. Environmental Circumscription and the Emergence of Social Complexity. URL: https://computationalsocialscience.org/wp-content/ uploads/2011/10/sscott-csssa-2011-Environmental-Circumscription-8pgproceedings-format.pdf.

Tallet, P., and Laisney, D. 2012. Iry Hor et Narmer au Sud Sinai (Ouadi Ameyra). Bulletin d'Institute Française Archeologique Orientale 112: 381-398.

Troy, L. 2003. Resource Management and Ideological Manifestation: The Towns and Cities of Ancient Egypt. URL: http://www.ibg.uu.se/digital Assets/9/9590_TroyAll.pdf.

Wengrow, D., Dee, M., Foster, S., Stevenson, A., and Ramsey, C. B., 2014. Cultural Convergence in the Neolithic of the Nile Valley: A Prehistoric Perspective on Egypt's Place in Africa. Antiquity 88 (339): 95-111.

Wilkinson, T. A. H. 1999. Early Dynastic Egypt. London and New York.

Wilkinson, T. A. H. 2000. Royal Annals of Ancient Egypt: The Palermo Stone $\&$ its Associated Fragments. London.

\section{APPENDIX}

Early Egypt in the state formation period scientific dating, Dee et al. 2013: 5 NB Beginning of Dynasty I, but not of the state, approx. $3150 \mathrm{BC}$

\begin{tabular}{|l|l|l|}
\hline Badarian & $68 \%$ confidence & $95 \%$ confidence \\
\hline Start & $4407-4308$ & $4489-4266$ \\
\hline End & $3800-3667$ & $4489-3616$ \\
\hline Duration & $529 / 709$ & $415 / 833$ \\
\hline Naqada I B/C & $3690-3605$ & $3731-3550$ \\
\hline Naqada II B/C & $3498-3413$ & $3562-3367$ \\
\hline Naqada IID/IIIA & $3352-3297$ & $3377-3238$ \\
\hline
\end{tabular}

